Godefridus J. H. van Hoof

\title{
Rethinking the Sources of International law
}

Kluwer, Dordrecht, 1983,322 S.

Among all institutions of international law, the sources of international law probably command the greatest interest which is intimately connected with the rôle of the sources in the system of international law. Yet, the popularity of this topic seems to have decreased lately. Publications in this field - even if numerous - are mostly fragmentary and actually concern specific questions, e. g. the law of treaties in the context of codification, interaction between treaties and custom, "soft law" etc. The book by Godefridus van Hoof is therefore of particular interest. The author has made a gread effort to analyse the whole question of sources and to reformulate some traditional ideas.

According to the author's point of view, the analysis of sources of international law must be preceded by the analysis of the notion of international law in its two aspects: binding force and close link between law and its environment, i. e. the society within which it operates. The rôle played by international law is being appreciated in the process of its formation. Van Hoof has considered three approaches to international law: the natural law approach, an analytical approach, and a sociological approach, in the policy-oriented version of M. McDougal; he has found them all untenable. He has decided to base his consideration on H. L. A. Hart's structural positivism, taking into account the division of international legal norms into two categories: primary and secondary norms, corresponding generally with substantive and formal rules. Secondary norms comprise the rules of recognition of international law. The author has founded his theory of sources upon this division.

The notion of "sources of law" of fers three different aspects: as a base of the binding force of international law (the principle pacta sunt servanda is here of fundamental importance); as a criterion for deciding whether the given norm is a norm of international law or not (the consent of States is decisive); and as relevant manifestations of international law. In all of these aspects the notion of "source" is strictly connected with the respective structure of international relations - every change in the system of relations involves changes within the system of sources of international law.

From this point of view Godefridus van Hoof analyses traditional sources of international law, mentioned in Article 38 of the Statute of the ICJ, and new ones, the importance of which is of ten disputed.

The author has considered the bindin - force of all international legal rules on this basis of a so-called three-stages theory (formulation of norms- the will to create law - the recognition of rules as legal norms). As to customary law, he has found practize as the most important factor in its formation while according to him an element of every process creating international legal norms (this argumentation is, however, not convincing) the opinio iuris is. Van Hoof is right in stating that the rôle of custom in contemporary international is lesser than the rôle of treaties as they contain more precise and concrete rules; however, it is difficult to accept fully this thesis that the formation of treaty norms 
advances faster than the formation of customary rules (taking into account the fact that usually much time lapses between the formulation of norms and their implementation. This is also a factor involving the increasing importance of customary law in some fields - especially when the customary rule is formulated on the basis of multilateral treaties.

In respect of general principles of international law, the author concludes that there is no agreement as to the content of this notion, so the principles can be regognized and applied exclusively in the framework of international judicial proceedings. Finally, van Hoof analyses so-called "soft law", recognizing its importance in certain fields and circumstances. In my opinion, such statement is controversial; the author has declared himself earlier as partisan of the idea that the consent of states is always the most important element in the process of formation of international law. The acts allegedly creating creating "soft law" can be considered exclusively as element of practice creating finally customary rules.

Chapter III seems to be a key passage of the book. G. van Hoof considers, in the context of his theory of sources, certain manifestations of the law creating will of states, dividing those manifestations into five categories: 1. abstract statements on the alleged rules of international law; 2. travaux préparatoires, 2. legal texts, 4 . follow-up procedure (enforcement of rules and eventually sanctions), and 5. subsequent practice (after recognizing the rule as binding). All manifestations can be regognized as factors connected with different sources and their importance must be considered in concreto.

The book by van Hoof systematizes to a certain degree the contemporary doctrine of the sources of international law. Its importance derives from the fact that the author proves that the will and consent of states always is an indispensable condition of the binding force of international law, and therefore from the fact that the author formulates important formal postulates concerning the identification of international law.

Władistaw Czapliński

Robert D. McKinlay/Richard Little

Global Problems and World Order

Francis Pinter, London, 1986, 275 S., $\mathfrak{E} 18.50$

Wir wären bei der Lösung weltweiter Probleme schon ein gutes Stück weiter, wenn wir uns wenigstens darüber einigen könnten, worin diese bestehen. Die Aussichten hierfür sind, folgt man McKinley und Little, gering. Um zu zeigen, warum dies so ist, unternehmen sie im kurzen, aber weit ausholenden Teil I des Buches eine Klärung des Begriffs "Ordnung". Aus seinen vielen Verwendungsmöglichkeiten: von der Abfolge geordneter Zahlenreihen bis zur detektivistischen Erzeugung von Ordnung durch die Hauptfigur in Ecos "Der Name der Rose" (übrigens William, nicht Henry of Baskerville), destillieren sie zwei Begriffselemente: Ordnung ist gekennzeichnet durch ein nach bestimmten Re- 